\title{
Slow growing scapular osteosarcoma in a Pug - a case report
}

\author{
Marko Pećin ${ }^{1 *}$, Ozren Smolec ${ }^{1}$, Andrea Gudan Kurilj², and Marija Lipar ${ }^{1}$ \\ ${ }^{I}$ Clinic for Surgery, Orthopaedics and Ophthalmology, Faculty of Veterinary Medicine, University of Zagreb, \\ Zagreb, Croatia \\ ${ }^{2}$ Department of Veterinary Pathology, Faculty of Veterinary Medicine, University of Zagreb, Zagreb, Croatia
}

\section{PEĆIN, M., O. SMOLEC, A. GUDAN KURILJ, M. LIPAR: Slow growing scapular osteosarcoma in a Pug - a case report. Vet. arhiv 88, 723-732, 2018.}

\section{ABSTRACT}

A scapular bone tumor in a 7-year-old male Pug is described. The Pug accidentally ran into a door six years before and started to limp on his front right leg. A small mass was noticed by the Pug's owners on his right shoulder which was ignored by the veterinarian. The mass increased in size until it became $9 \mathrm{~cm}$ in diameter and the dog was not using his leg occasionally. Finally the dog was referred to the Surgery, Ophthalmology and Orthopedics Clinic for further diagnostics. Following complete clinical and orthopedic examinations, an X-ray of the right scapula was performed and a neoplasia of the scapulae was suspected. A biopsy and histopathological examination was recommended in order to rule out osteosarcoma. The histopathological examination established the diagnosis of a highly productive, osteoblastic osteosarcoma of the right scapula with pulmonary metastasis. Prognosis was unfavorable due to metastases to the lungs evidenced by the X-ray. We report a case concerning an untreated scapular neoplasia with X-ray detectable lung metastases upon presentation at the Clinic. Proper diagnosis should be based on clinical examination, radiograph evaluation of the process and histopathological findings after bone biopsy. Blunt trauma can be a trigger for development of slow growing periosteal osteosarcoma, as described here. Treatment often include subtotal scapulectomy or forequarter amputation with adjuvant chemotherapy. Despite aggressive treatment, scapular osteosarcoma has a poor prognosis with low median survival time and disease free interval in dogs. Unfortunately the Pug's owners refused the recommended treatment and the dog was euthanized 2 months later.

Key words: osteosarcoma; scapula; histopathology; pug

\section{Introduction}

Osteosarcoma (OSA) is the most common form of malignant bone cancer in dogs and it occurs 10 times more frequently than in people (FENGER et al., 2014). Both clinical and molecular evidence suggests that human and canine OSA share many key features, such as the presence of a microscopic metastatic disease at diagnosis, tumor location

\footnotetext{
*Corresponding author:

Assist. Prof. Marko Pećin, PhD, DVM., Faculty of Veterinary Medicine, University of Zagreb, Heinzelova 55, 10000 Zagreb, Croatia, Phone: +385 12390 391; Fax: +385 12390 380; E-mail: mpecin@vef.hr
} 
and sometimes the development of chemotherapy resistant metastases (FENGER et al., 2014). OSA is a primary malignant neoplasm of mesenchymal origin that gives rise to a variety of patterns. It always includes the production of bone by malignant osteoblasts (DERNELL et al., 2001; THOMPSON and POOL, 2002a; WATERS and COOLEY, 2002). Scapular OSA is relatively uncommon and accounts for up to $13 \%$ of all axial osteosarcomas. OSA of the axial skeleton accounts for $25 \%$ of all OSA and $59 \%$ of OSA in dogs weighting less than $15 \mathrm{~kg}$ (COOLEY and WALTERS, 1997). Nevertheless, OSA is the most common malignant scapular tumor. Overall prognosis for scapular OSA is similar to appendicular OSA (MONTINARO et al. 2013).

The purpose of this case report was to describe a case of untreated slow growing canine scapular osteosarcoma in a 7 year old Pug.

\section{Materials and methods}

History. A 7-year-old Pug was presented for $2^{\text {nd }}$ degree limping on his front right leg for more than six months. The Pug accidentally ran into a door six years before and started to limp on his front right leg. The scapula was sore for a a few days so the owners visited a veterinarian who noticed a small mass on the right scapula just over the acromion but ignored it assuming the dog was limping for other reasons. The mass grew larger over the 6 year period although the veterinarian constantly ignored the problem, explaining there was no need for surgical treatment. A radiograph of the scapula was performed by the veterinarian and bone neoplasia-like changes were noticed without bone lysis. The dog was released without a biopsy or additional treatment. The scapular mass was ignored as still "not important" almost 6 years later. The limping became worse so the Pug was referred to the Surgery, Orthopedics and Ophthalmology Clinic of the Faculty of Veterinary medicine in Zagreb, for orthopedic examination and possible $\mathrm{X}$-rays.

Two months after the biopsy the dog was euthanized due to paraneoplastic syndrome and the necropsy was performed.

Clinical examination. The dog was overweight $(10.6 \mathrm{~kg})$, with body temperature and heart rate within the normal ranges. His respiratory rate was elevated (60 per minute). The submandibular and prescapular lymphatic nodules were slightly enlarged. He was suffering from brachycephalic syndrome, with closed nostrils and elongated soft palate.

Upon clinical examination, a large spherical mass, measuring approximately $9 \mathrm{~cm}$ in diameter, affecting the right scapula, as well as generalized muscle atrophy of the right forelimb were observed. A poorly demarcated, hard, solid mass with irregular and rough, surface and edges was palpated. During palpation the shoulder was painful as a result of passive pulling. The Pug soon became aggressive due to excessive pain. The mass seemed to be incorporated within the bone. 
The range of motion of the right shoulder was limited and painful, especially in extension and rotation of the shoulder. It was impossible to palpate the spina scapulae and processus acromialis or other anatomical structures of the scapulae and shoulder joint.

Complete blood count, biochemistry profile of kidney and liver function and urinalysis were unremarkable apart from indicating thrombocytosis and mild hypochromic microcytic anemia. The serum alkaline phosphatase level was within normal values. Thrombocytosis and mild hypochromic microcytic anemia were probably due to the chronic nature of the disease and affected the bone marrow.
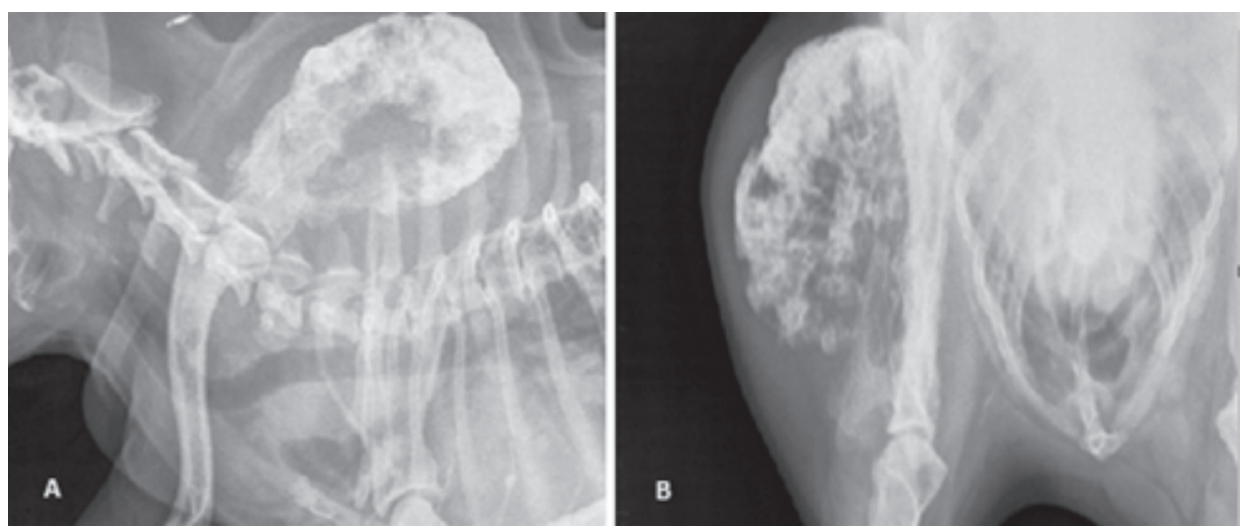

Fig. 1. A. View of the profile projection of the thorax and right scapula, showing osteolytic changes in the right scapula, with lung metastasis. Normal anatomical structures of the right scapula were unrecognizable. 1B: A mass nine $\mathrm{cm}$ in diameter was discovered with zones of newly formed bone and osteolysis.

A radiograph was performed of the right front leg from the elbow joint proximally with the thorax in standard antero-posterial and latero-lateral (AP/LL) projections. On the radiographic examination, both the right lateral and the dorsoventral views of the front limb showed a distinctive area of osteolytic and osteogenic activity within the scapula (Fig. 1). There was a new bone formation extended in a palisading (or so-called sunburst) pattern radiating from the adjacent normal bone (Fig. 2), while the surrounding soft tissues appeared swollen. Radiographic changes were consistent with appendicular OSA, with a mixed pattern of lytic and productive changes predominating. A cluster of periosteal reaction had been noted on the (LL) projection of the right scapulae. The proximal anatomical margins of the scapula were hard to identify (Fig. 1). The spina scapulae had lytic changes with loss of normal anatomical structures. The shoulder joint and lung parenchyma transparency were normal except two small metastatic changes less than $1 \mathrm{~cm}$ in diameter detected on the cardiac and diaphragmatic lobes of the lungs. 

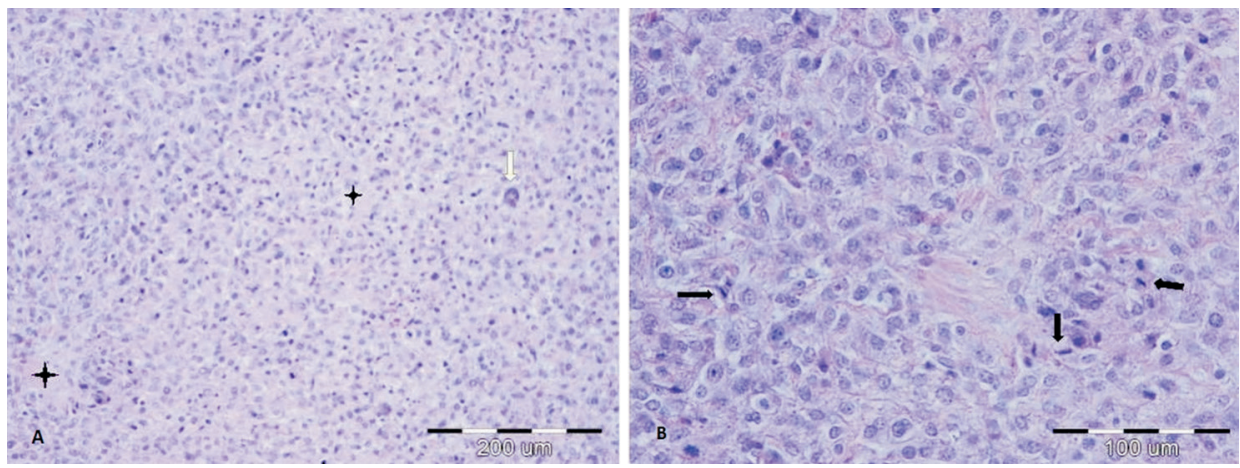

Fig. 2. A. Osteosarcoma (primary tumor); neoplastic spindle cells surround the osteoid (black stars); cells show mild pleomorphism and a giant cell is present (arrow). H\&E, $\times 10$.

2B: Osteosarcoma (primary tumor), higher magnification showing spindle neoplastic cells surrounding the osteoid and a few mitotic figures are present (arrows). H\&E, $\times 40$.

The initial diagnostic considerations included two main differentials: skeletal neoplasia and granuloma caused by chronic inflammation. In cases in which the signalment and radiographic findings prove insufficient, bone biopsy is necessary for a definite diagnosis (THRALL, 1998). Therefore bone biopsy was mandatory. Regarding the size and the nature of the tumor, a $7 \mathrm{~mm}$ Michele trephine was used to obtain large samples.

Pre-anesthetic preparation and anesthesia. As mentioned before, the dog was brachycephalic with indications of brachycephalic syndrome. Acepromazine maleate was used in premedication, along with dexamethasone and metoclopramide administered 30 minutes preoperatively. Induction of anesthesia included midazolam and propofol. General anesthesia was maintained by $2.5 \%$ sevoflurane applied through an endotracheal tube. Transdermal fentanyl patch was given a day earlier in doses of $25 \mu \mathrm{g} / \mathrm{h}$ and removed 5 days later. Pain management was maintained with methadone, NSAID carprofen per os for the next 5 days. The American Society of Anesthesiologists classification (ASA) of the patient was 3 .

Surgical procedure. A fibrous capsule was detected about one centimeter thick. It was without blood vessels and of hard elastic consistency. There was a reddish grey tumor of the consistency of bone tissue under the capsule. During the biopsy by $7 \mathrm{~mm}$ Michele trephine, a viscose liquid (necrotic tissue) appeared. Biopsy samples were taken from two places determined by the most distinctive changes on the earlier radiograph.

Histopathological findings, biopsy of primary tumor. Two irregular pieces of soft consistency tissue measuring $19 \times 5 \mathrm{~mm}$, and three cylindrically shaped samples of bone tissue, $7 \mathrm{~mm}$ in diameter, were examined histologically. An unencapsulated, infiltrative, densely cellular neoplasm, composed of spindle cells (osteoblasts) often surrounding 
foci of eosinophilic, homogenous matrixes (osteoid) were noticed. Neoplastic cells were arranged in interlacing streams and bundles on a fine fibrovascular stroma; the cells had indistinct cell borders and a small to moderate amount of eosinophilic cytoplasm (Fig. 2). The nuclei were oval, with finely stippled chromatin and usually 1-2 nucleoli. There was mild anisocytosis and anisokaryosis. Mitotic figures averaged 2-3 per high power field (HPF). Multifocally, there were infrequent bi- or multinuclear neoplastic cells. Small areas of necrosis were multifocally scattered throughout the neoplasm.
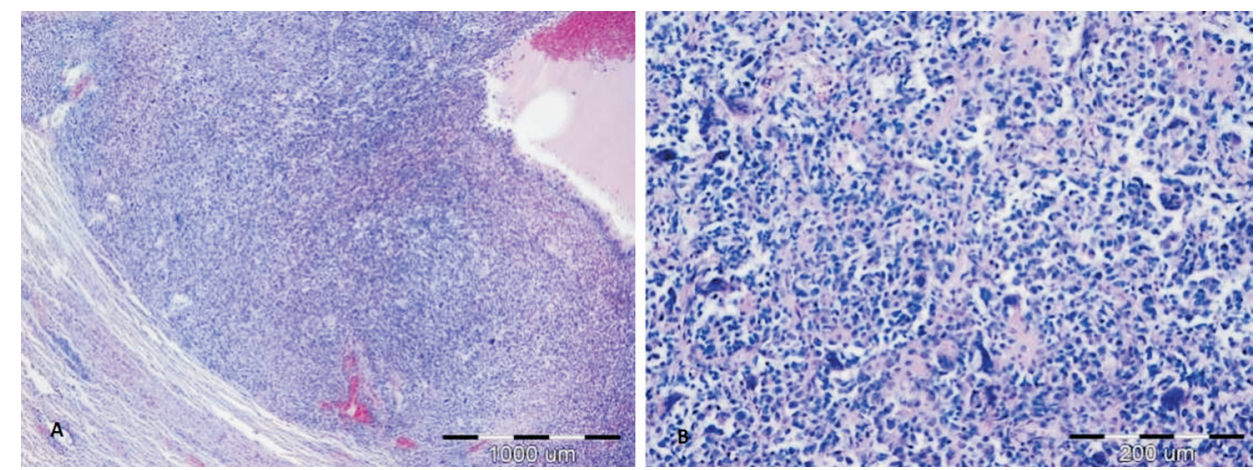

Fig. 3. A. Lung, metastasis of osteosarcoma: round mass composed of neoplastic osteoblasts and large number of multinuclear cells compressing the adjacent lung parenchyma; upper right corner - space lined by neoplastic cells and filled with amorphous, eosinophilic material admixed with erythrocytes. H\&E, $\times 4$. 3B: Lung, metastasis of osteosarcoma: higher magnification showing spindle and multinuclear neoplastic cells surrounding osteoid. $\mathrm{H} \& \mathrm{E}, \times 10$.

Lung metastases description. The histopathological and necropsy examination established the diagnosis of highly productive, osteoblastic osteosarcoma of the right scapula with pulmonary metastasis. Round, infiltrative, unencapsulated, densely cellular masses that measure $2 \mathrm{~mm}$ to $2 \mathrm{~cm}$ and compressing the adjacent parenchyma were noted. They were composed of similar neoplastic spindle cells (as described in the primary neoplasm) that also surrounded foci of the osteoid (Fig. 3). The neoplastic cells showed a high degree of anisocytosis and anisokaryosis, and there were large number of multinucleated neoplastic cells (containing up to 20 nuclei). Occasionally, there were spaces formed, lined by neoplastic cells and filled with amorphous, eosinophilic material admixed with erythrocytes. In the center of the metastatic nodules, large areas of necrosis and hemorrhage were noticed.

\section{Discussion}

Bones are organs composed of different elements, such as bone tissue, cartilaginous and fibrous tissue, bone marrow, nerves and blood vessels. All these elements can 
undergo neoplastic transformation, alone or in various interactions. Osteoma is a rare benign neoplasm originated from mesenchimal tissue and osteoblasts, while malignant osteosarcoma has the same cell origin (WEISBRODE, 2007). In domestic animals, osteosarcoma can be histopathologically classified as poorly differentiated, osteoblastic, chondroblastic, fibroblastic, telangiectatic and giant cell types (SLAYTER et al., 1994; KIRPENSTEIJN et al., 2002). Radiographically, OSA should mainly be differentiated from other bone tumors, such as osteomas, bacterial osteomyelitis and the less frequently encountered mycotic osteomyelitis. These bone infections may result in aggressive lesions. However, there may be other radiographic evidence, such as pulmonary infiltrates or thoracic lymphadenopathy or clinical signs of systemic debilitation, that support the diagnosis of an infectious process.

Recent studies have shown that increased activity of serum alkaline phosphatase (ALKP) prior to treatment is associated with a poor prognosis for dogs with appendicular OSA (GARZOTTO et al., 2000; STERNBERG et al., 2013). In our case report, the Pug had normal values of alkaline phosphatase, despite progressive lytic changes in the scapula. Normal values of ALKP in our case were not a contributing factor for good prognosis because the dog was euthanized 2 months later.

As mentioned earlier, OSA is the most common primary bone tumor in dogs. In general, it is a very aggressive malignant neoplasia, with a high rate of metastasis (DERNELL, et al., 2001; THOMPSON and POOL, 2002a; WATERS and COOLEY, 2002). Its biological behavior seems to vary depending on location, age or breed (DERNELL, et al., 2001; THOMPSON and POOL, 2002b; WATERS and COOLEY, 2002). In cases in which the signalment and radiographic evidence prove insufficient, bone biopsy is necessary for a definite diagnosis. Although there is a broad range in the age of onset, OSA is a disease that mostly occurs in middle-aged to older dogs, with a median age of 7 years (DERNELL, et al., 2001; THOMPSON and POOL, 2002b; WATERS and COOLEY, 2002). The youngest dog reported with OSA was a 3-month-old puppy with an affected mandible (GINEL et al., 1996). In our case the dog was 7 years old with anamnestic data of a 6 year old trauma and consequently a slow growing mass. It is possible that the trauma triggered the slow growing osteosarcoma or benign tumor with malignant alteration after 6 years. We can only assume what really happened with the tumor because biopsy and radiographic data were unavailable before referral. This is the main limitation of this case report. Due to the histopathological data of a highly productive, osteoblastic osteosarcoma, it is more likely that osteosarcoma had newer origin.

The metaphyseal region of the long bones is the most common primary site (DERNELL, et al., 2001; THOMPSON and POOL, 2002b; WATERS and COOLEY, 2002). Although OSA of irregular bones is not generally rare (PHILIPS et al., 1986; LUCROY et al., 2001; BLEIER et al., 2003), scapular OSA is quite uncommon. CAVALCANTI 
et al., (2004) indicated that the most frequently affected bones were the radius and ulna, femur and tibia, while the scapula was less frequently affected. Concerning bone tumors other than osteosarcoma, metastases occur in about $25 \%$ of cases in small dogs and less than 5\% in large dogs (COOLEY and WATERS, 1997). Metastasis is the most common complication of cancer leading to death. OSA metastasis is very common and arises early in the course of the disease. It is mainly asymptomatic, as in our case. In this case report the Pug was panting upon admission to the Clinic and it was hard to determine if he had a problem with his lungs due to metastatic changes, or brachycephalic syndrome due to closed nostrils and elongated soft plate. The only sign of the neoplasia was occasional non weight bearing and a painless mass on the scapula. The right scapula was affected by the osteosarcoma, that was non-resectable. Subtotal scapulectomy was not possible in the current case due to the tumor's size and invasive growth affecting tissue near the shoulder joint. After positive diagnosis of scapular OSA, limb amputation was suggested to the Pug's owners to provide excellent pain relief. The owners refused scapulectomy or adjuvant chemotherapy, and requested only pain suppressive therapy. In the paper by MONTINARO et al. (2013) subtotal scapulectomy was performed in $42.9 \%$ dogs with scapular OSA. Adjunctive chemotherapy had a statistical significant positive effect on the disease free interval (DFI) and median survival time (MST). Limb use was fair to excellent for most dogs (MOTINARO et al., 2013). Overall prognosis for scapular OSA is similar to appendicular OSA at other sites, and use of adjunctive chemotherapy prolonged the overall DFI and MST (MOTINARO et al., 2013). This case report lacks evidence of the primary bone lesion and bone tumor type. From the history we can only assume that the primary tumor was a slow growing bone tumor caused by blunt trauma in the young animal, later histologically proven to be an osteosarcoma. Lack of further diagnostics, such as computed tomography or magnetic resonance, due to the owners' unwillingness and lack of interest in treatment options such as forequarter amputation with adjuvant chemotherapy, werw the limitation of this case report. Nevertheless palliative treatment was the only option for this dog and he was euthanized 2 months later due to his bad condition. Evidence of osteosarcoma derived from the osteoma is missing.

\section{Conclusion}

This case report describes a case concerning a scapular neoplasia histologically differentiated as osteosarcoma with radiographically detectable lung metastases upon presentation at the clinic. Few case series with median survival times have been reported, but individual survival times are usually less than 12 months after diagnosis for dogs with scapular OSA (DICKERSON et al., 2001; NORTON et al, 2006). Proper diagnosis should be based on clinical examination, radiographic evaluation of the process and histopathological findings. Without adjuvant therapy, amputation should be considered as pain control palliative care. The prognosis for dogs with scapular tumors depends on 
the tumor type. Metastasis in cases of scapular OSA is very common with poor prognosis leading to early death. The one-year survival rate achieved with amputation alone is less than 10 percent and the mean survival time is four to five months. Bone biopsy is mandatory for diagnostic of osteosarcoma. Slow growing malignant bone tumors, if not diagnosed and treated properly have a poor prognosis.

\section{References}

BLEIER, T. H., P. LEWITSCHEK, M REINACHER (2003): Canine osteosarcoma of the penile bone. J. Vet. Med. Anat. Physiol. Path. Clin. Med. 50, 397-398.

CAVAlCANTI, J. N., E. M. I. AMStalden, J. L. GUERRA, L. C. MAGNA (2004): Osteosarcoma in dogs: clinical-morphological study and prognostic correlation. Brazil J. Vet. Res. Anim. Sci. 41, 299-305.

DOI: $10.1590 /$ S1413-95962004000500002

COOLEY, D. M., D. J. WATERS (1997): Skeletal neoplasms of small dogs: a retrospective study and literature review. J. Am. Anim. Hosp. Assoc. 33, 11-23.

DOI: $10.5326 / 15473317-33-1-11$

DERNELL, W. S., R. C. STRAW, S. J. WITHROW (2001): Tumors of the skeletal system. Small Animal Clinical Oncology, $3^{\text {rd }}$ ed., (Withrow, S. J., MacEwen, E. G. Saunders, Eds.), Philadelphia, pp. 378-417.

DiCKerson, M. E., R. L. PAGE, T. A. LAdUE, M. L. HAUCK, D. E. THRALL, M. E. STEBBINS, G. S. PRICE (2001): Retrospective analysis of axial skeleton osteosarcoma in 22 large-breed dogs. J. Vet. Intern. Med. 15, 120-124.

DOI: 10.1111/j.1939-1676.2001.tb01242.x

FENGER, J. M., C. A. LONDON, W. C. KISSEBERTH (2014): Canine osteosarcoma: a naturally occurring disease to inform pediatric oncology. ILAR J. 55, 69-85

DOI: 10.1093/ilar/ilu009

GARZOTTO, C. K., J. BERG, W. E. HOFFMANN, W. M. RAND (2000): Prognostic significance of serum alkaline phosphatase activity in canine appendicular osteosarcoma. J. Vet. Intern. Med. 14, 587-592.

DOI: $10.1111 / \mathrm{j} .1939-1676.2000 . t b 02281 . x$

GINEL, P. J., M. NOVALES, J. M. MOLLEDA, J. PEREZ, E. MOZOS (1996): Mandibular fibroblastic osteosarcoma in a three-month-old dog. Vet. Rec. 139, 120-121.

DOI: $10.1136 /$ vr.139.5.120

KIRPENSTEIJN, J., M. KIK, G. R. RUTTEMAN, E. TESKE (2002): Prognostic significance of a new histologic grading system for canine osteosarcoma. Vet. Pathol. 39, 240-246.

DOI: $10.1354 / \mathrm{vp} .39-2-240$

LUCROY, M. D., J. N. PECK, J. R. BERRY (2001): Osteosarcoma of the patella with pulmonary metastases in a dog. Vet. Radiol. Ultrasound 42, 218-220.

DOI: 10.1111/j.1740-8261.2001.tb00927.x 
MONTINARO, V., S. E. BOSTON, P. BURACCO, W. T. CULP, G. ROMANELLI, R. STRAW, S. RYAN (2013): Clinical outcome of 42 dogs with scapular tumors treated by scapulectomy: a Veterinary Society of Surgical Oncology (VSSO) retrospective study (1995-2010). Vet. Surg. 42, 943-950.

DOI: 10.1111/j.1532-950X.2013.12066.x

NORTON, C., C. M. DRENEN, S. G. EMMS (2006): Subtotal scapulectomy as treatment for scapular tumor in dog: A case report of six cases. Aust. Vet. J. 84, 364-366.

DOI: $10.1111 /$ j.1751-0813.2006.00033.x

PHILIPS, L., H. HAGAR, R. PARKER, D. YANIK (1986): Osteosarcoma with a pathological fracture in a six-month-old dog. Vet. Radiol. 27, 18-19.

DOI: 10.1111/j.1740-8261.1986.tb00614.x

SLAYTER, M. V., T. R. BOOSINGER, R. R. POOL, K. DAMMRICH, W. MISDORP, S. LARSEN (1994): Malignant tumors. World Health Organization Histologic Classification of Bone and Joint Tumors of Domestic Animals., Vol 1, $2^{\text {nd }}$ series. Armed Forces Institute of Pathology, American Registry of Pathology and the World Health Organization Collaborating Center for Comparative Oncology, Washington, DC., pp. 7-11.

STERNBERG, R. A., H. C. PONDENIS, X. YANG, M. A. MITCHELL, R. T. O'BRIEN, L. D. GARRETT, W. G. HELFERICH, W. E. HOFFMANN, T. M. FAN (2013): Association between absolute tumor burden and serum bone-specific alkaline phosphata se in canine appendicular osteosarcoma. J. Vet. Intern. Med. 27, 955-963.

DOI: 10.1111 jvim. 12121

THOMPSON, K. G., R. R. POOL (2002a): Tumors of bone. Tumors in Domestic Animals. $4^{\text {th }}$ ed., (Meuten, D. J., Ed.), Iowa state press, Ames, IA, pp. 245-248.

THOMPSON, K. G., R. R. POOL (2002b): Tumors of bone. Tumors in Domestic Animals. $4^{\text {th }}$ ed., (Meuten, D. J., Ed.), Iowa state press, Ames, IA, pp. 263-283.

THRALL, D. E. (1998): Bone tumors versus bone infections. Textbook of Veterinary Diagnostic Radiology, $3^{\text {rd }}$ ed., (Thrall, D. E., Ed.), Saunders, pp. 161-168.

WATERS, D. J., D. M. COOLEY (2002): Skeletal neoplasms. Cancer in Dogs and Cats, Medical and Surgical management, $2^{\text {nd }}$ ed., (Morrison, W., Ed.), Teton NewMedia, Jackson, Wyoming, pp. 611-625.

WEISBRODE, S. E. (2007): Diseases of bone. Pathologic Basis of Veterinary Disease. $4^{\text {th }}$ ed., (McGavin, M. D., J. F. Zachary, Eds.), Mosby Elsevier, pp. 1064-1094.

Received: 1 September 2017

Accepted: 8 May 2018

Vet. arhiv 88 (5), 723-732, 2018 


\section{PEĆIN, M., O. SMOLEC, A. GUDAN KURILJ, M. LIPAR: Spororastući osteosarkom lopatice u psa mops pasmine - prikaz slučaja. Vet. arhiv 88, 723-732, 2018.}

\section{SAŽETAK}

Opisan je tumor lopatice u sedmogodišnjega muškog mopsa. Kao štene, slučajno je naletio na vrata i počeo šepati na prednju desnu nogu. Vlasnici su primijetili malu tvorbu, oteklinu na desnoj lopatici koju je veterinar ignorirao. Tvorba se s godinama povećavala do veličine od $9 \mathrm{~cm}$ u promjeru, a pas je povremeno šepao. Nakon kliničkog i ortopedskog pregleda te rendgenografskog oslikavanja desne lopatice posumnjalo se na neoplaziju lopatice. Preporučena je biopsija i histopatološka pretraga tvorbe kako bi se potvrdila sumnja na osteosarkom. Histopatološki nalaz upućivao je na vrlo produktivan, osteoblastični osteosarkom desne lopatice s plućnim metastazama. Prognoza je bila nepovoljna zbog rendgenografski dokazanih metastaza na plućima Kao što je ovdje opisano, trauma može biti okidač za razvoj spororastućeg periostalnog osteosarcoma, a pravilno dijagnosticiranje treba temeljiti na kliničkom pregledu, rendgenografskoj procjeni procesa $\mathrm{i}$ histopatološkom nalazu. Liječenje osteosarkoma lopatice često uključuje potpunu skapulektomiju ili amputaciju prednje noge s odgovarajućom kemoterapijom. Unatoč agresivnom liječenju, skapularni osteosarkom ima lošu prognozu, s niskim srednjim vremenom preživljenja i kratkim razdobljem bez bolesti u pasa. Nažalost, vlasnici mopsa odbili su preporučeno liječenje i pas je nakon dva mjeseca eutanaziran.

Ključne riječi: osteosarkom; lopatica; klinički i histopatološki nalaz; mops 